\title{
Technological and socio-economic study of akandji, a neglected traditional foodstuff made from corn (Zea mays $\mathrm{L}_{\text {.) }}$ in Benin
}

\author{
Célestin C. K. TCHEKESSI ${ }^{1 *}$, Ornella I. CHOUCOUNOU ${ }^{1}$, da Raymond MATHA ${ }^{2}$, \\ G. Justin GANDEHO ${ }^{1}$, S.A. Pivot $\mathrm{SACHI}^{1}$, S. Jultesse BANON ${ }^{1}$, \\ T. M. Roseline BLEOUSSI ${ }^{1}$, Anayce DJOGBE ${ }^{1}$, T. Karl ASSOGBA ${ }^{1}$ and \\ P. Innocent BOKOSSA YAOU ${ }^{1}$
}

\begin{abstract}
${ }^{1}$ Food Health Safety Research Unit (URSSA), Microbiology and Food Technology Laboratory (LA.MI.T. A), Department of Plant Biology, Faculty of Sciences and Technologies (FAST) of Abomey-Calavi University (UAC), 04BP 1107 Cotonou, Benin ; Tel. : (+229) 95962942, E-mail : innobokos@ gmail.com;

${ }^{2}$ Faculté des Sciences Economiques et de Gestion (FASEG) de l'Université d'Abomey-Calavi (UAC), Cotonou, Benin ; Tel. : (00229) 97742728 ; email: raymond.damatha@faseg.uac.bj

* Corresponding author; 04 BP 888 Cotonou, Benin, Tel. : +229 97810040 / +22995302763,

E-mail: tchecokice@yahoo.fr
\end{abstract}

Received: 28-05-2021

Accepted: 16-08-2021

Published: $31-08-2021$

\begin{abstract}
Foodcrafts, active in Benin, offer a variety of products including akandji. It is a traditional bread made of corn consumed in South Benin. This work aimed to achieving a technological and socio-economic study related to akandji production and marketing activities in Benin. To do this, the methodology adopted was to conduct a pre-survey and a survey in the form of semi-structured interviews based on a questionnaire in the communes of Abomey, Bohicon and Ouidah (Pahou). After that, production monitoring was carried out with the three oldest akandji producers. The results showed that the production and sale of akandji were secular, exclusively female activities practised by women from Fon socio-cultural and sociolinguistic group. The profit per kg received by akandji producers in Abomey (266 XOF) was similar to that received by akandji producers in Pahou (256 XOF). The daily receipts for weekends and holidays were higher than those for working days in the survey localities. Furthermore, the results of the technological study showed that akandji manufacturing process in Abomey differs from that of Pahou. This process in Abomey involved the malting operation unlike that of Pahou. Fermentation times (12h), cooking times (1h) and production times (6 days) in Abomey exceeded fermentation times (1h30min), cooking times (45min) and production times $(6 \mathrm{~h})$ in Pahou. In contrast, the fermentation $\left(27^{\circ} \mathrm{C}\right)$ and cooking $\left(100{ }^{\circ} \mathrm{C}\right)$ temperatures of akandji at Abomey were lower than those of fermentation $\left(31^{\circ} \mathrm{C}\right)$ and cooking $\left(178^{\circ} \mathrm{C}\right)$ in Pahou. The production of akandji is a profitable activity that strengthens the social status of the producer and ensures important socio-community functions by providing an appropriate local food for traditional rites and festivals and maintains sales markets firmly rooted in society. (C) 2021 International Formulae Group. All rights reserved.
\end{abstract}

Keywords: Akandji, traditional food manufacturing process, socio-economic, Benin 


\section{INTRODUCTION}

In Africa, and particularly in Benin, the agrifood industrial sector is poorly developed. Thus, a significant proportion of agricultural products is processed through food crafts (Dossou et al., 2015). Indigenous processing practices are transmitted and perpetuated over generations through family education and the traditional learning system (Tchekessi et al., 2014). With large sums of money involved, the food industry is undoubtedly one of the most important sectors of employment for a large proportion of the population, including entire families, especially women in developing countries (Aholou-Yéyi, 2007; FAO, 2009). In Benin, the trade in street food prepared within the food crafts generate daily income which amounted to between 1,500 and 15,000 XOF per saleswoman (FAO, 1996 cited by Tchekessi et al., 2014). Nago et al. (1990) have shown that this sector plays an important role in maintaining national food security through the processing of local products. The most widely used local products are cereals, of which maize is the most processed raw material in this sector. Ranked the second most cultivated cereal in the world after wheat, maize is the most energetic and most economical cereal in terms of production (Charcosset et al., 2009; Nuss et al., 2011). In addition, from this cereal, comes a wide range of very varied foods such as dishes, boiled, drinks, cakes, donuts, sauces, baked dishes etc. Akandji, cereal product, is a kind of traditional bread made from corn flour (Onzo et al., 2013). It is an endangered food commodity as demonstrated by Adjanohoun et al. (2015). Called kandji in Yoruba and Goun, or bolou in Adja, akandji is produced and marketed in South Benin mostly in the communes of Ouidah and Abomey in the streets and on the outskirts of the tracks. Like all street food, the production of akandji is subject to many constraints such as exposure to bad weather, external contamination and therefore poses a public health problem. Despite the importance of its production and marketing, no or very few studies have been devoted to this product. A socio-economic and technological study related to akandji manufacturing process and marketing activities should therefore be carried out. The objective of this study is to evaluate the technology of akandji production in Benin. Specifically, the study aims to identify the different raw materials and technologies used in the production of akandji; to assess the state of hygiene during production and sale, as well as the economic profitability of the product.

\section{MATERIALS AND METHODS Study area}

The geographical framework of this study is the South of Benin more precisely in the departments of Atlantic and Zou. The study was carried out in the municipalities of Abomey (Hounli), Bohicon (Bohicon) and Ouidah (Pahou) because they are considered to be Communes with high production, sales and consumption of akandji in Benin. The Municipality of Abomey is situated between $1^{\circ}$ $50^{\prime \prime}$ and $2^{\circ} 5^{\prime}$ East longitude and $7^{\circ} 0^{\prime}$ and $7^{\circ}$ $10^{\prime \prime}$ North latitude. Bohicon is at latitude $6^{\circ} 55$ and $7^{\circ} 08 \mathrm{~N}$, longitude $1^{\circ} 58$ and $2^{\circ} 24 \mathrm{E}$, and Ouidah is at latitude $2^{\circ} 15$ and $2^{\circ} 15 \mathrm{~N}$ and between latitude $6^{\circ} 15$ and $6^{\circ} 30 \mathrm{E}$.

\section{Survey material}

Questionnaires incorporating sociocultural, technological and economic questions were sent to akandji producers and sellers.

\section{Plant material}

The corn variety used is the whitecoloured maize (Zea mays L.) locally referred to as Adjakouin or Nikkikouin (in the local language Fon) recognized and chosen for this purpose by akandji producers. A lot of maize was bought at the market of Pahou and Abomey. Banana (Musa sapientum), Greater Senegal Arum (Lasiomorpha senegalensis) and marante (Thalia geniculata) leaves, respectively called kokoéman, toungoman and afléman in Fon language were used for the packaging of akandji. 


\section{Other ingredients}

Refined sugar, salt, instant yeast and water from the National Water Society of Benin (SONEB) were also used.

\section{Field survey}

The survey, divided into three phases, took the form of semi-structured interviews and the observation of the actors at work. These phases are the exploratory phase, the data collection phase, the data analysis phase.

\section{Exploratory phase}

This step identified the different areas of akandji production, marketing and consumption in Benin. The choice of survey communes is based on the information collected from the resource persons, but also with the literature search. The communes of Ouidah, Abomey, and Bohicon have targeted as the areas of high production, sales and consumption of akandji in Benin. This phase took place in focus group. Once the preinvestigation was completed, the cities of Pahou, Abomey and Bohicon were chosen as cities to be investigated.

\section{Data collection phase}

The second phase consisted in administering a questionnaire to the producers and sellers of akandji in Pahou, Abomey and Bohicon. The survey was carried out in the immediate vicinity of the production, sale and consumption places especially in houses, the markets of Pahou, Abomey; sites identified during the exploratory phase. The individual survey was carried out using the snowball method developed by Goodman in 1961 (Wilhelm, 2014) and involved 23 players in akandji production and marketing activity.

\section{Survey on Akandji manufacturing process}

This survey aimed to learning about the different stages of the akandji production process, the different varieties of raw materials used and to identify the risk practices associated with them. It took place in two stages. Initially, a questionnaire was administering to 23 akandji producers and sellers in Pahou (17), Abomey (06) and Bohicon (00). In a second stage, the three oldest akandji producers were selected and followed during the manufacture of akandji. Informations related to socio-economic and cultural characteristics, unit production operations of akandji and the different raw materials used in its production were then collected.

\section{Processing of survey data}

In Benin and more generally in Africa, local perceptions of phenomena and practices are strongly influenced by customs and practices, which themselves depend on sociocultural groups (Gnanglè et al., 2011). As a result, the subjects surveyed were grouped under a single identified socio-cultural group, namely the Fon. In this group, subjects were grouped into three age categories (youth $=0$ to 35 years; adult $=35$ to 60 years; 60 years and older) and sex (Assogbadjo et al., 2008). Thus, in total, 03 socio-cultural types taking into account the combination of the main sociocultural groups, age and sex were considered as presented in Table 1.

For each person surveyed, the perception index of each organoleptic characteristic as well as the perceptions of akandji and other processes were determined. For each category, an average perception index was calculated for each characteristic based on the average value of the perception indices for this characteristic by the individuals making up the group in question. A matrix of indices of perception for organoleptic characteristics was established. This matrix was subjected to a Primary Component Analysis (PCA) according to Bello et al. (2017) using MiniTab 2014 software, to describe the existing relationships between perceptions related to changes in the state of different organoleptic characteristics. The same analytical approach related to the establishment of socio-cultural groups was carried out for the assessment of organoleptic characteristics in relation to the socio-cultural group but also in relation to the origin locality of akandji. For each socio-cultural group and locality, the persons who opted for the different varieties were counted. The resulting contingency table was submitted at Simple Correspondence Factor Analysis (SFA) using Minitab 14 software (Bello et al., 2017). The 
results of the various analyses were presented in tables and figures.

\section{Statistical analysis}

The data collected were compiled using the 2016 Excel spreadsheet and then coded and processed using the Statistical Package for Social Sciences (SPSS) version 20.0 (Norusis, 2002) for descriptive statistics determination in terms of percentage and average. The quantitative data were then subjected to analysis of variance (ANOVA) using the Statistical Analysis System (SAS) version 9.2 software according to Balogoun et al. (2014) and MiniTab 2014. Comparisons of multiple means were made with the Student NewmanKeuls test (Dagnelie, 1986). The level of significance was $5 \%(\mathrm{p}<0.05)$.

\section{RESULTS}

\section{Socio-economic and demographic characteristics}

Akandji, corn bread, is a food native to South Benin where the cultivation of corn is more widespread. It is found in Ouidah (Pahou), and on the Abomey-Bohicon axis. This corn bread was brought by the «Dada» that is to say ancestors according to the respondents. When their wives did not cook early, akandji allowed them to survive until the meal. Akandji, often accompanied by " ataclè (bean-based donut) », also served as provisions during the wars. This inspired a Fon adage that says « nu e gbo atacle de etchi bo e fuń hwa yeo ni egbo clecle o gbe djin e na yi » which means «akandji does not get moldy quickly ». It did not only provide them with strength, but was also easily transportable and kept for a long time. In addition to the lucrative activity associated with akandji, the production and consumption of akandji occur on several occasions. It is served in Abomey during the «Adjagbé» (ritual of exit of the twins), the «Ninsounhwéhoun», funeral rites, and consultation of the oracle. It is given as food to vodoun (divinities) Dan and Tohossou.

\section{Socio-cultural profile of respondents}

Table 2 presents the results of the distribution of respondents by sex, age, ethnicity, nationality, social status and educational attainment. From it, it appears that the production and sale of akandji are exclusively female activities. The producers, all of Beninese nationality and Fon people were mostly young $(56.50 \%)$, housewives $(69.60 \%)$ and uneducated $(56.50 \%)$. The variance analysis and the Student Newman Keuls test showed that the age of the actresses in the production and sale of akandji residing in Abomey is not significantly different ( $\mathrm{p}$ $<0.05$ ) from that of Pahou (Figure 1).

The Factorial Analysis of Correspondences (AFC) carried out on data related to the occupational category of the respondents revealed that the production of akandji is the prerogative of Adults and Old Women Fon both in Abomey and Pahou. Young Women Fon was only akandji resellers (Figure 2).

\section{Source of akandji manufacturing process acquisition}

It can be deduced that $17.4 \%$ of respondents had acquired this technology by inheritance compared to only $4.3 \%$ who had acquired it by apprenticeship. Figure 3 illustrates this distribution of respondents by source of technology acquisition.

\section{Socio-economic characterization \\ Yield, Production cost and profit margin}

Table 3 presents the results of Student Newman Keuls' tests on yield, unit price, revenues, cost of production and profit margin in the two akandji production municipalities. Analysis of this table shows that akandji production was less profitable in Pahou than in Abomey at the 5\% threshold. On the other hand, the unit price, revenues and cost of production were higher in Pahou than in Abomey at the 5\% threshold. But there is no significant difference between the profit margins of the two survey areas $(\mathrm{p}<0.05)$. 


\section{Daily akandji receipts in both survey areas}

Table 4 presents the results of the Student Newman Keuls test on daily receipts at the two akandji production locations. It reveals that the minimum revenues for weekends and holidays were higher in Abomey than in Ouidah. However, there was no significant difference between the minimum and maximum receipts for working days and the maximum receipts for weekends and holidays in the two regions surveyed.

\section{Characterization of traditional akandji manufacturing technologies by producers Corn variety}

At the end of the survey, the targeted producers reveal that in $100 \%$ of the cases, that the variety of maize used for the production of akandji was the white variety used for the preparation of the white paste called Adjakouin or Nikkikouin (in Fon language).

\section{Production equipment}

The material involved in the production of akandji consisted of basins, cups, baskets, trays, sieves, strainers, clean cloths, plastic buckets, pots, a pallet, dishes, a mill, a fireplace and a traditional oven. The water used for the production was potable water.

\section{Technical parameters of technologies}

As a result of this survey, the technologies according to the producers showed the same cleaning temperature (28-30 ${ }^{\circ} \mathrm{C}$ ) and washing temperature $\left(28-30{ }^{\circ} \mathrm{C}\right)$. However, the number of people washing and cleaning could vary. They agreed that the cleaning and washing times depended on the purity of the corn, but also on the quantity of akandji to be produced. In addition to these similarities, there were some distinctive unit operations. Table 5 shows the similarities and dissimilarities of these two akandji production technologies. According to the data collected, each region corresponded to a specific technology. Our studies have shown that in Abomey, there is the malting operation, which was not the case in Pahou. To this end, we have tried to investigate the similarities and dissimilarities of technologies from one city to another presented in Table 5.
In addition, different parameters related to unit operations such as grind, fermentation and cooking found at the two technologies as well as akandji production time were subjected to the Student Newman Keuls test for analysis. The results of the test performed on these parameters are recorded in Table 6. From the latter, it appears that the grind cost and the fermentation temperature did not vary significantly at the 5\% threshold from one region to another $(p>0.05)$. This same table shows that fermentation and production had a very high duration at Abomey than at Pahou (p $<0.001$ ). As for cooking, it had a very high duration in Abomey than in Pahou ( $\mathrm{p}<0.01)$. In contrast, the cooking temperature of akandji in Pahou was very high compare to the cooking temperature of akandji in Abomey ( $\mathrm{p}<0.001$ ).

\section{Different traditional akandji production technologies identified \\ Manufacturing process of Akandji in Pahou}

Corn grains for akandji production are sorted, washed and drained. The drained corn grains are sent to the mill for crushing. The crushed corn is then sifted, resulting in flour, gritz and bran. The gritz and the corn flour are moistened with water and then sent back to the mill for a second milling. The resulting flour is left to cool. One third of it is washed in water and added to boiling water on the fire. This produces a slurry that is allowed to cool completely at room temperature. The rest of the flour, sugar (optional), salt and yeast to the dough on the floor are then incorporated. Some producers also add wheat flour. The whole is kneaded until the ingredients integrate well into the dough. The latter is covered it afterwards and rest for about $1 \mathrm{~h}$. After this time, the dough is packed in either banana, marante or large arum leaves from Senegal; it is baked for about $45 \mathrm{~min}$ in a preheated oven. The images on Figure 4 below illustrate the different stages of this production.

$$
\text { Production tracking }
$$
and characterization of a traditional manufacturing process of akandji allowed us to obtain the diagram below (Figure 5). 
Manufacturing process of Akandji in Abomey

The cleaned corn kernels undergo the malting process. The malted corn kernels are sent to the mill for milling. Water is added (moistened) to the malted corn kernels in the manner of making the mawè (fermented corn flour paste) (but with a greater quantity of water: it is said in fon «ezin lifin ». The whole is homogenized and left for a few hours in the sun. Let rest all night (10h - 12h). The next day, water is added to make the mixture a little more liquid. This dough is packed in banana leaves and steamed for 1 hour. The images below illustrate the different stages of this preparation (Figure 6).

Monitoring the akandji preparation process and characterization of traditional akandji production technologies allowed us to establish the production diagram below (Figure 7).

\section{Organoleptic characteristics According to the locality}

Tables 7 and 8 respectively present the organoleptic characteristics of the two akandji varieties according to their origin of production and the eigen - Value of the first two components. The analysis in table 8 shows that the two axes have enabled to analyse $100 \%$ of the data.

The results of the Correspondence Factor Analysis (AFC) carried out on data related to the organoleptic characteristics of akandji showed that in Abomey, akandji was white, compact, sweet acid, less hard and preserved for about 5 days according to the producers (Figure 8). On the other hand, akandji produced by women in Pahou was whitish, spongy, hard, salty sweet acid and kept for 2-5 days. However, akandji produced by women from the two survey localities had a smooth appearance.

\section{Depending on the socio-cultural group}

Figure 9 shows the distribution of respondents by age and sex. Figure 9 shows that the Abomey respondents were made up only of young and adult women in equal proportion. In contrast, in Pahou, the majority of respondents were young women $(58,8 \%)$ followed by adults $(35,3 \%)$ and old $(5,9 \%)$ women.

\section{Eigen value axis Proportion Cumulative proportion}

The eigen values of the first three main components are shown in Table 9. Table 9 shows that $99 \%$ of the data collected were analysed in relation to the two axes.

The projection of the 3 socio-cultural groups (Figure 10) into the axis system defined by the organoleptic characteristics showed that the AFF produced whitish, smooth, spongy, hard, and salty sweet acid akandji that was preserved for five days. In contrast, JFF akandji kept for two to five days. VFF, on the other hand, produced akandji white, compact, less hard, sweet acid.

Table 1: Effectives associated with the 03 socio-cultural types studied $(n=23)$.

\begin{tabular}{l|l|l}
\hline Socio-cultural types & Codes & Workforce \\
\hline Adults Women Fon & AFF (AWF) & 9 \\
Young Women Fon & JFF (YWF) & 13 \\
Old Women Fon & VFF (OWF) & 1 \\
\hline Total & 23 \\
\hline
\end{tabular}




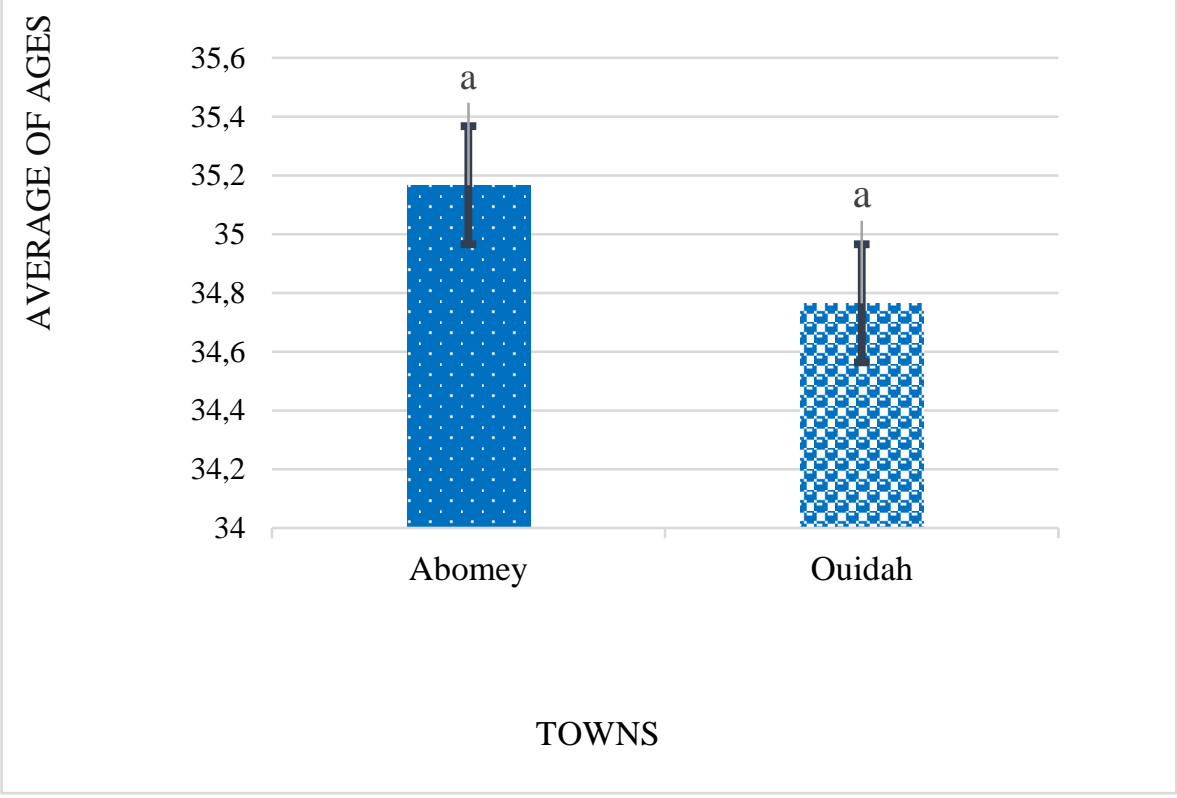

Figure 1: Ages of respondents.

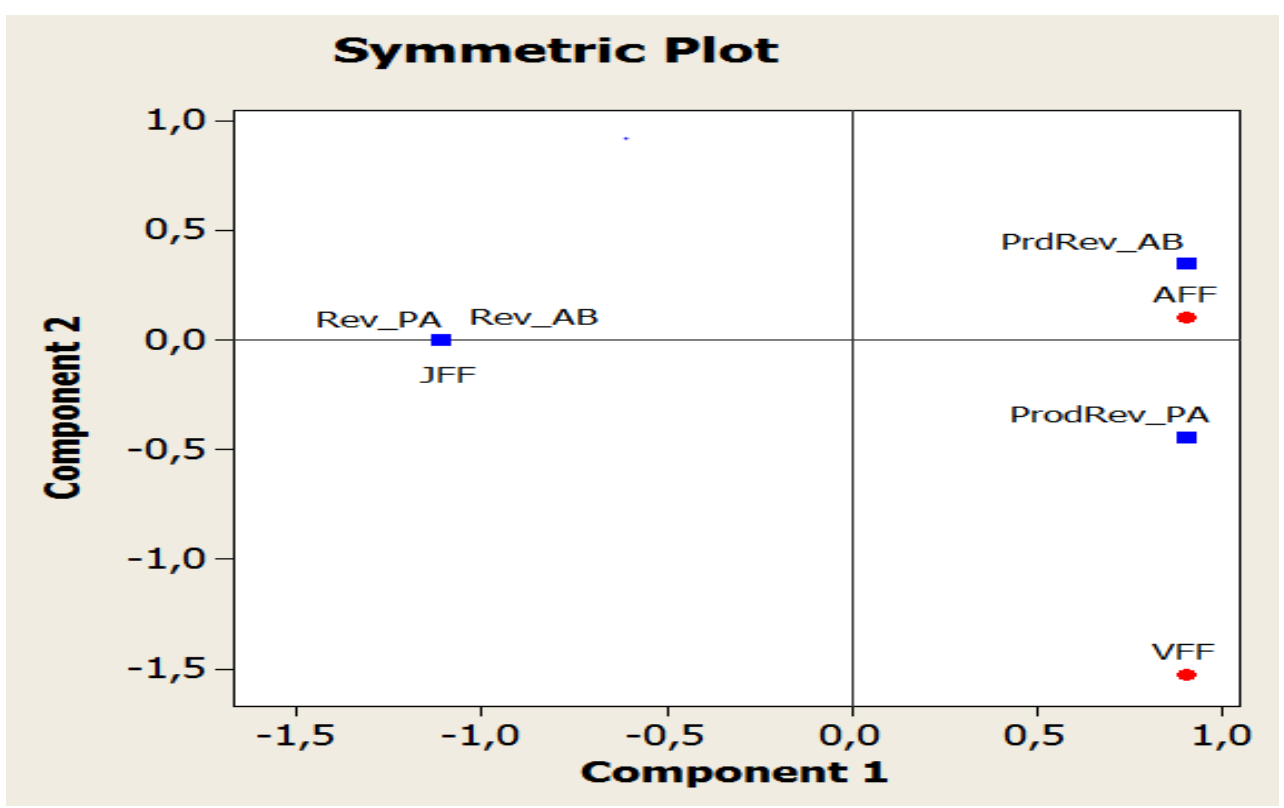

Figure 2: Category of respondents: projection of socio-cultural groups in the factor axis system following a correspondence factor analysis (AFC). 


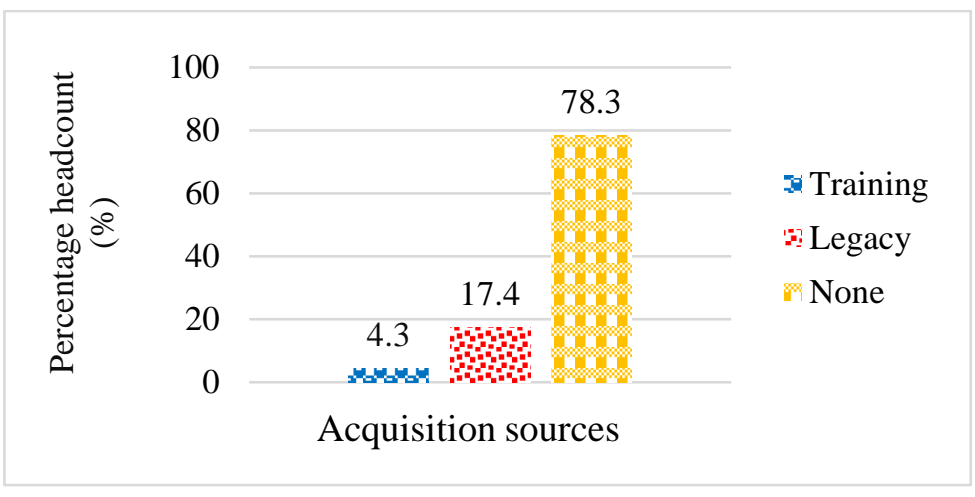

Figure 3: Distribution of respondents by acquisition source.

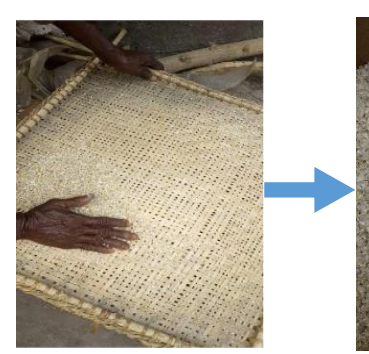

Sieving

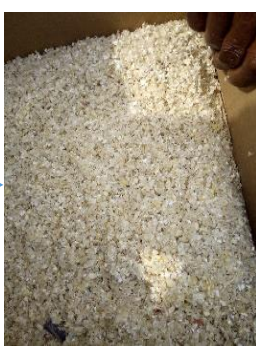

Corn bran

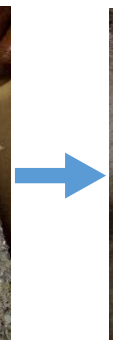

Corn flour

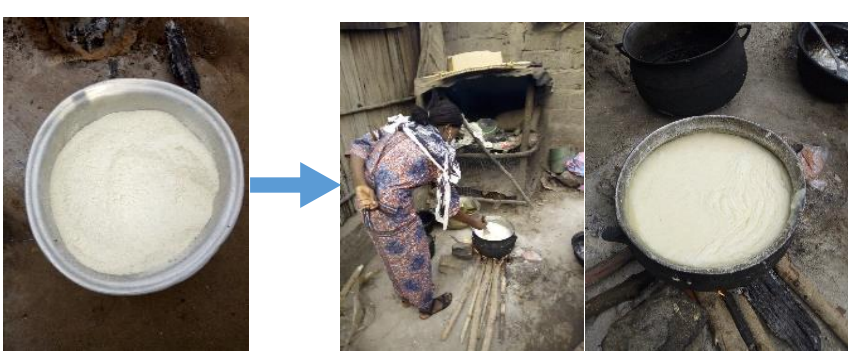

Preparation of the porridge

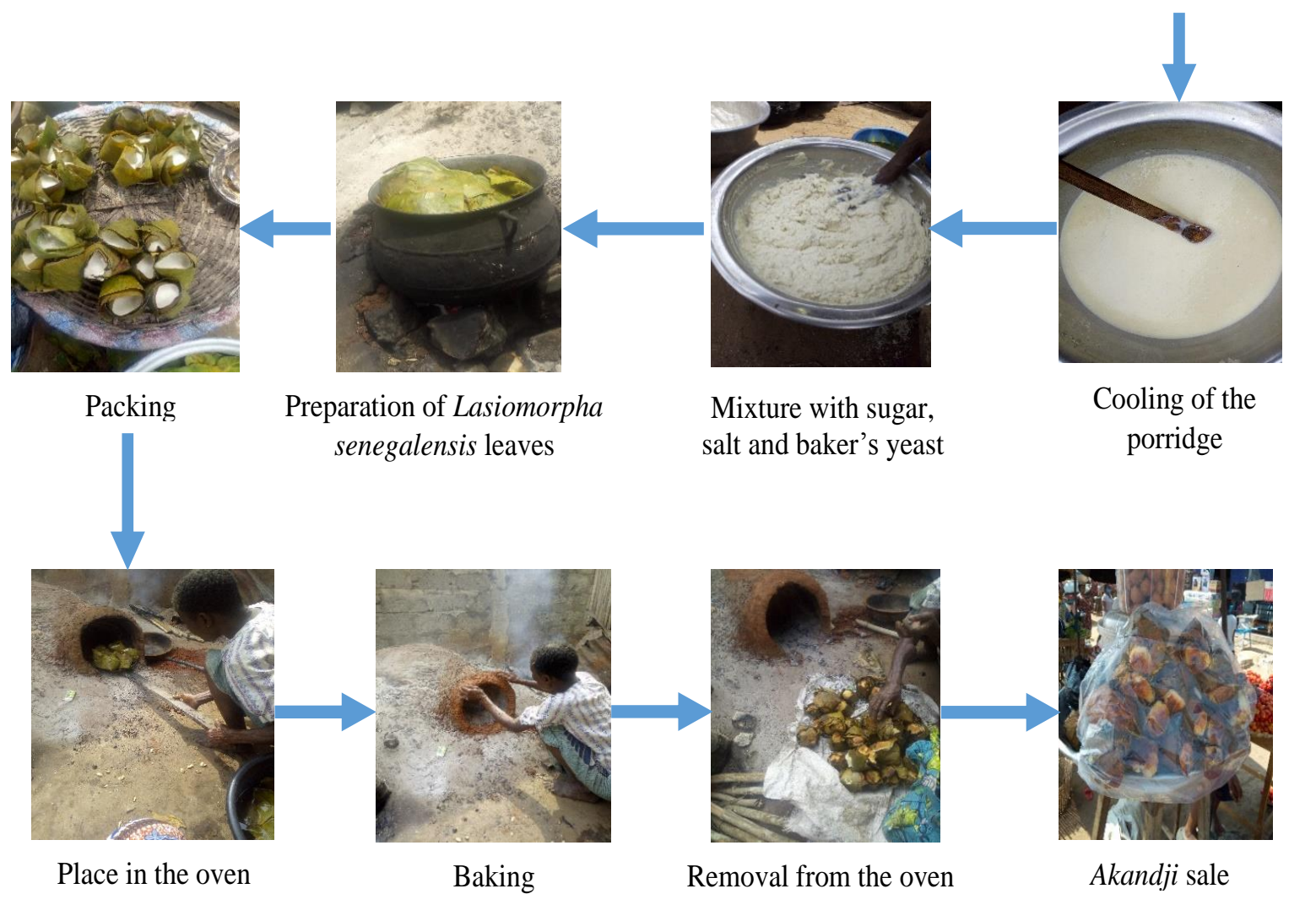

Figure 4: Production stages of akandji in Pahou. 


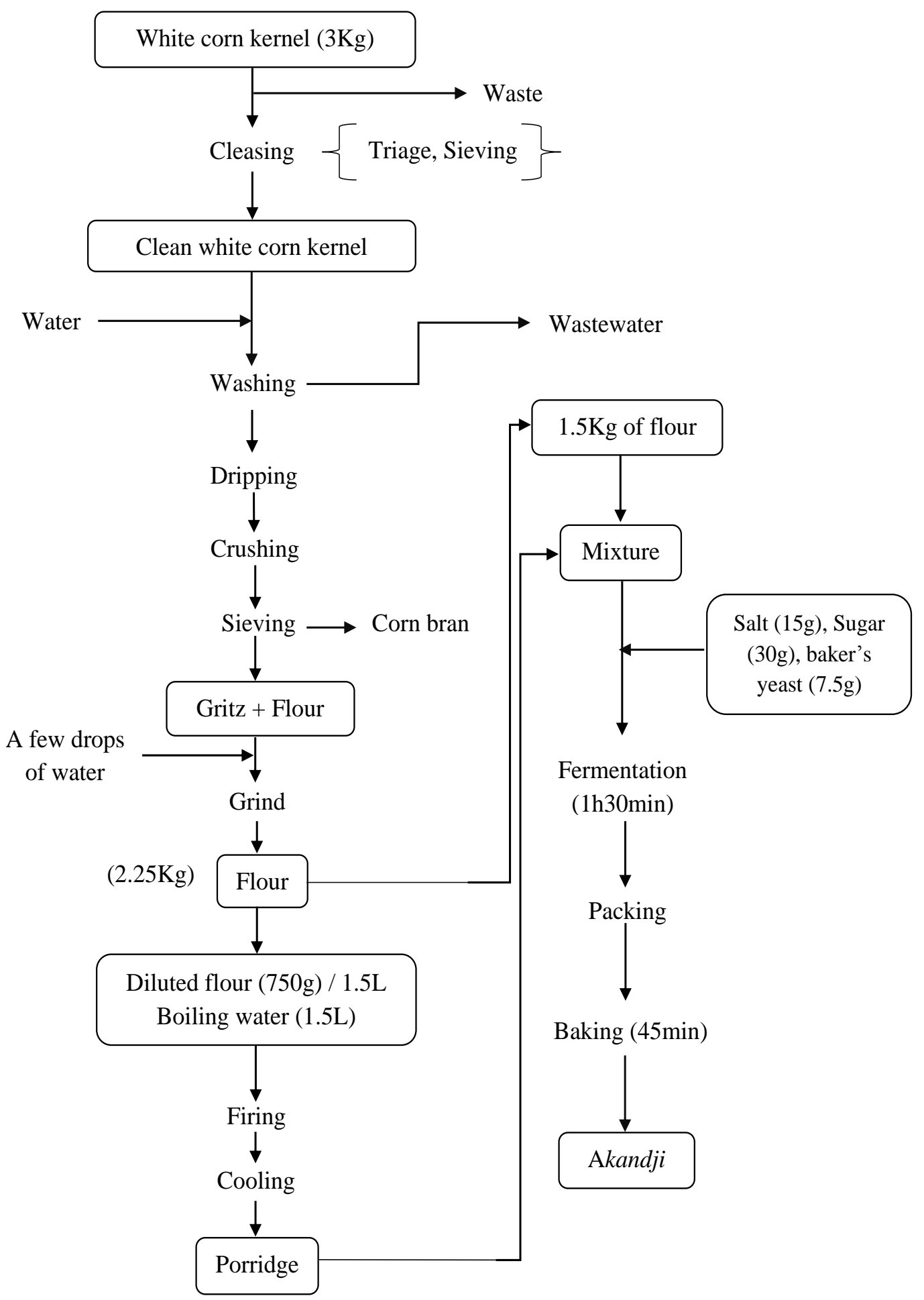

Figure 5: Traditional akandji production technology diagram at Pahou. 


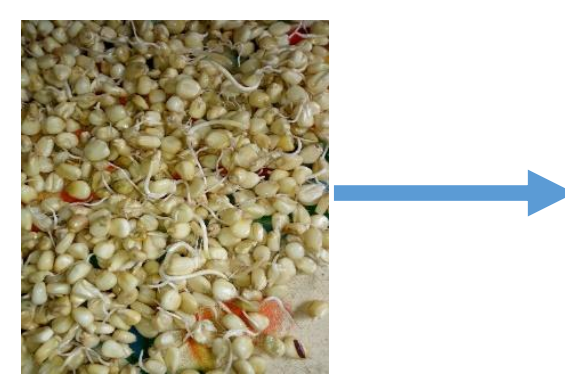

Malted corn

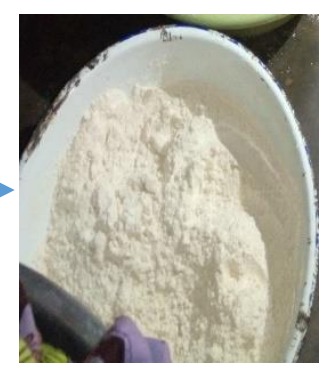

Malted corn flour

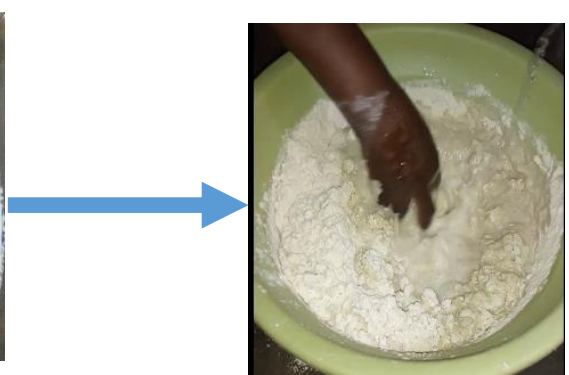

Addition of water

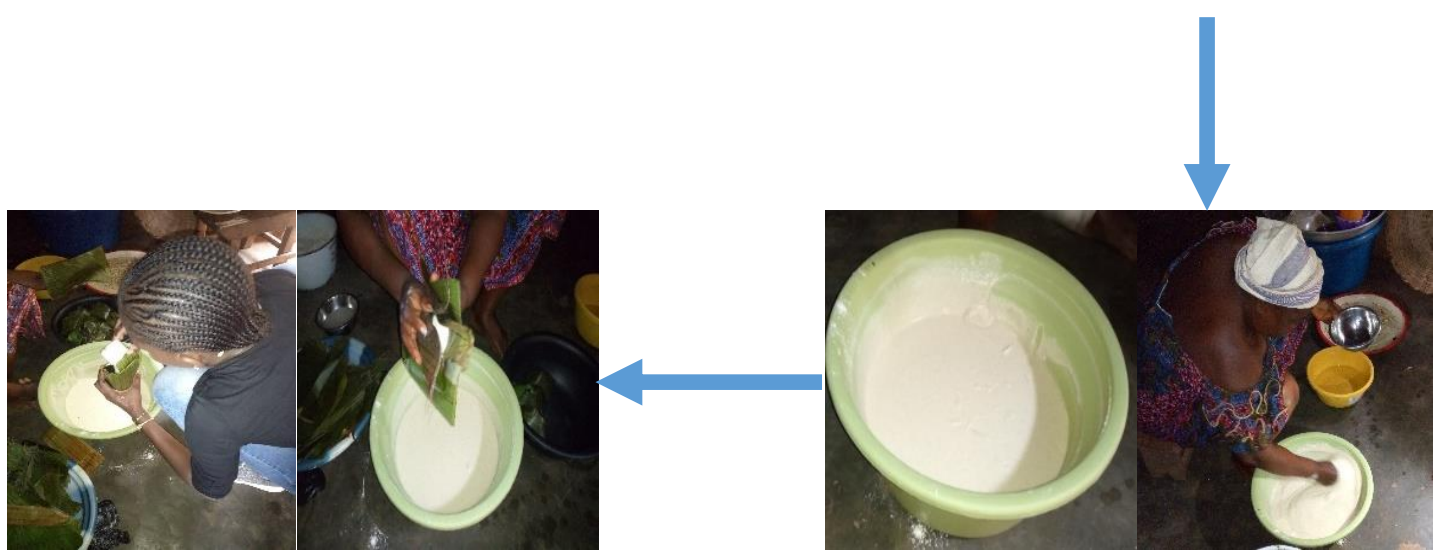

Packing

Mixing and obtaining of soft dough

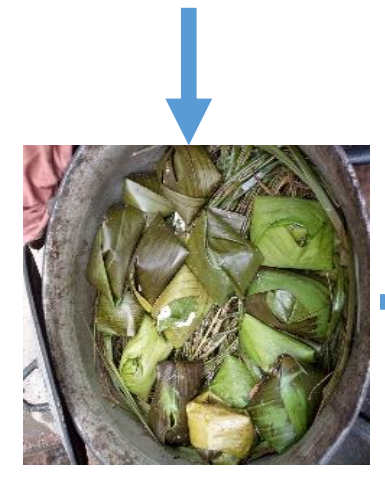

Layout of packed soft dough

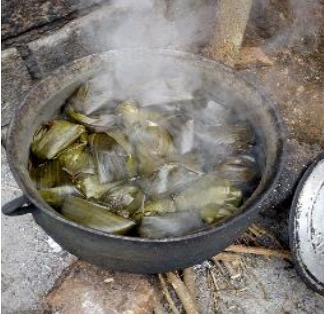

Steam cooking

Figure 6: Stages of akandji production in Abomey. 


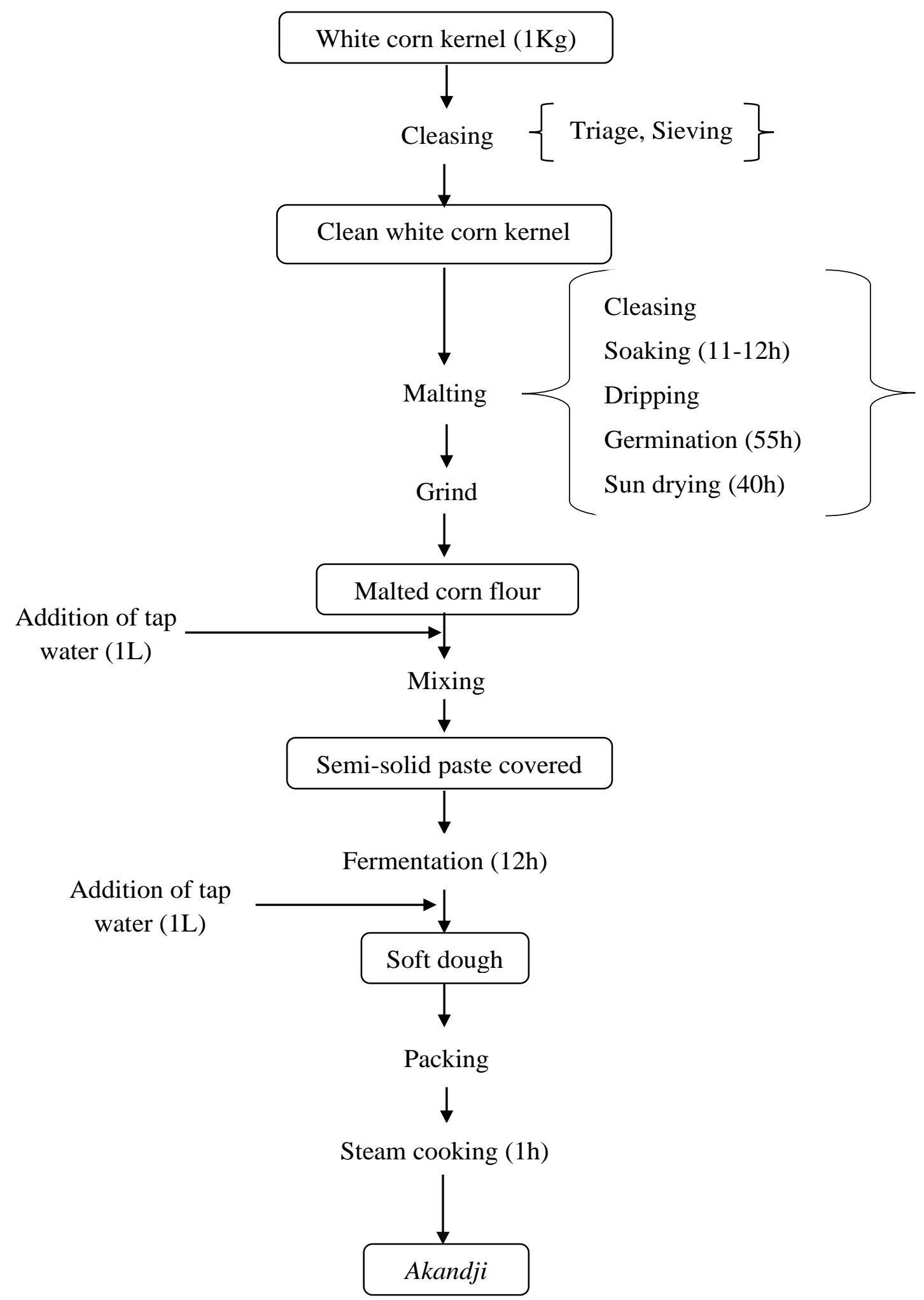

Figure 7: Traditional technology diagram of akandji production in Abomey and Bohicon. 


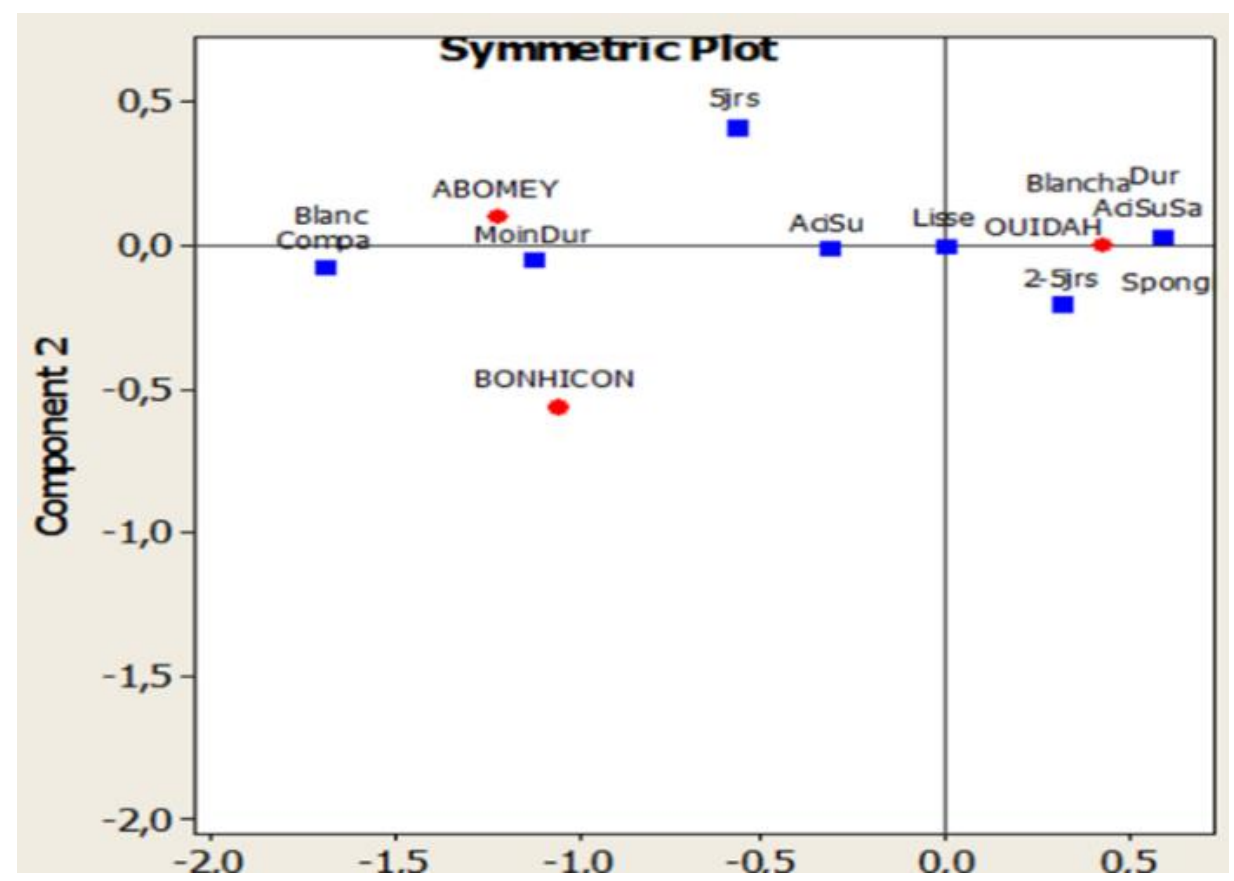

Legend: Compa $=$ Compact $;$ MoinDur $=$ less Hard $) ; \mathrm{AciSu}=$ Sweet Acid $) ;$ Blancha $=($ Whistish $) ;$ AciSuSa $=$ Sweet Salt Acid ; Spong=Spongy

Figure 8: Organoleptic characteristics of akandji ; projection of localities in the factorial axis system following correspondence factor analysis (AFC).

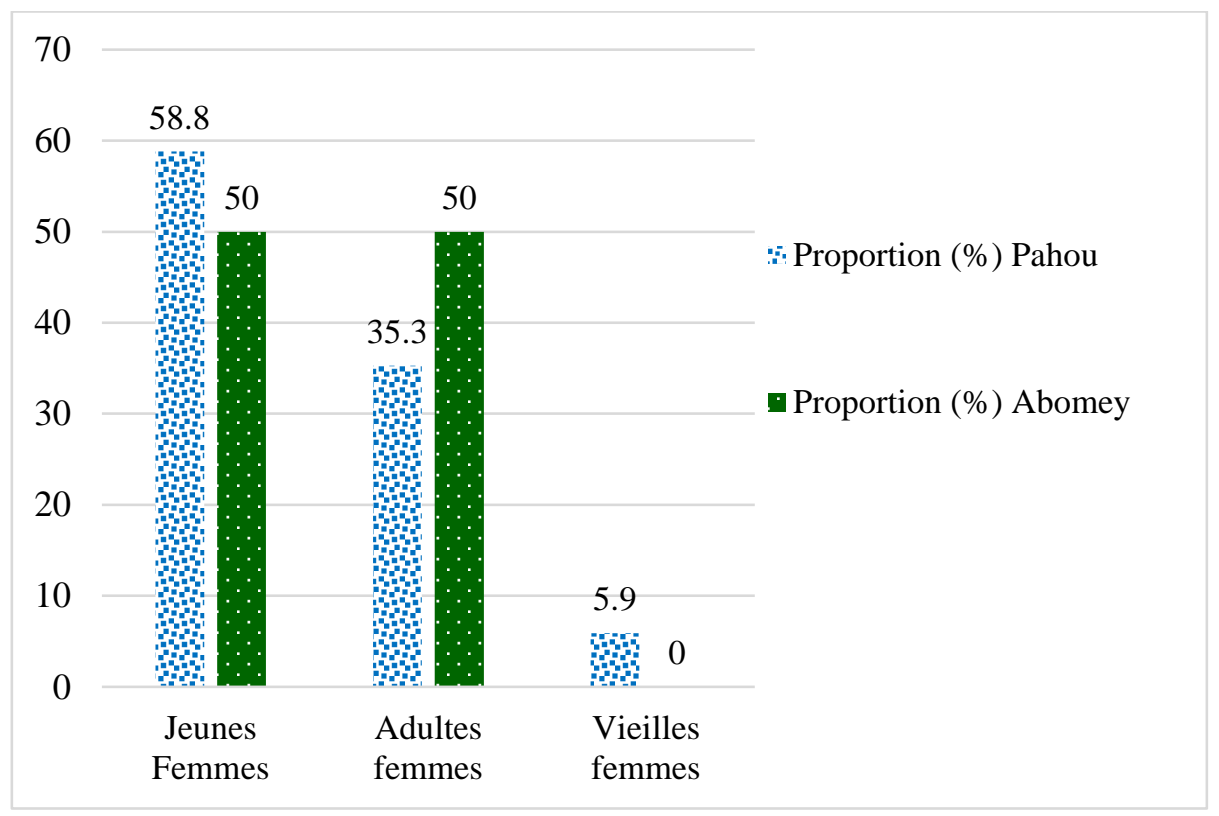

Figure 9: Distribution of female producers and female resellers by age. 

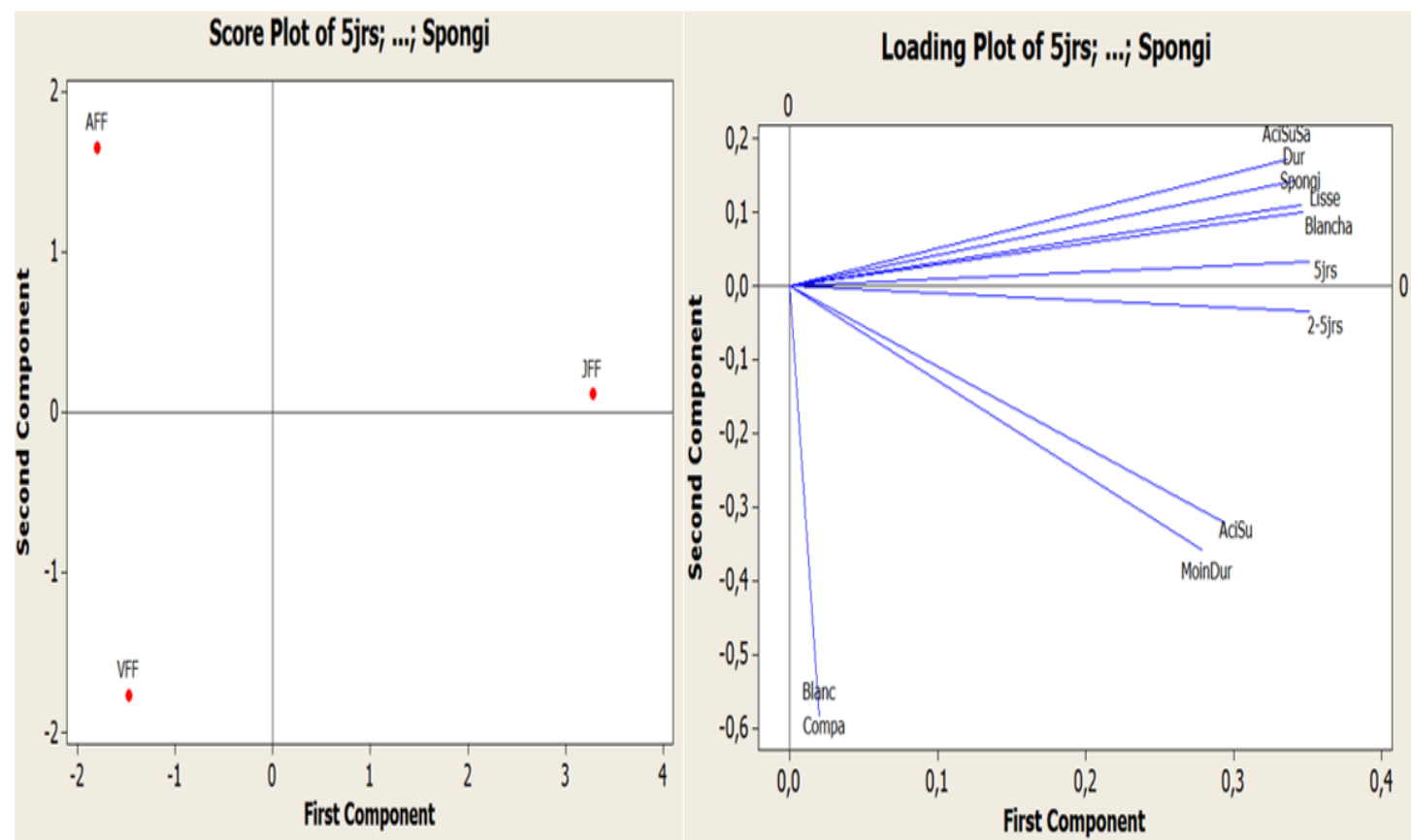

Legend: $\mathrm{AFF}=$ Adult Women Fon $; \mathrm{JFF}=$ Young Women Fon $;$ VFF $=$ Old Women Fon $;$ AciSuSa $=$ Sweet Acid Salty ; Spongi $=$ Spongy $;$ Blancha $=$ Whitish $;$ jrs $=$ days $;$ AciSu $=$ Sweet Acid, MoinDur $=$ Less hard, Compa $=$ Compact

Figure 10: Organoleptic characteristics studied from a Principal Component Analysis (PCA): projection of socio-cultural groups and organoleptic characteristics in the factor axis system.

\section{DISCUSSION}

The various surveys conducted show that akandji production and marketing activities were exclusively female (Table 2), as were those of gowé (Tchekessi, 2012), foura (Moussé, 2018), Ablo (Banon, 2012) and gnomy (traditional fermented millet donut) in Côte d'Ivoire (N'goran-Aw et al., 2017). It is a food typically native to the Fon ethnic group of South Benin as shown in Table 2. More than half of female producers were not enrolled in school $(56.50 \%)$, housewives $(69.60 \%)$ and young women $(56.50 \%)$. The succession to the parents, the profitability of the activity or the provision of financial assistance in the home are all reasons that pushed the producers and sellers of akandji to choose this sector of activity. These same reasons were cited by Tchekessi et al. (2013) for the choice of the sector of activity by the gowé producers and by Moussé (2018) for the choice of the sector of activity by the foura producers. Whether in Abomey or Pahou, akandji production activity was carried out only by Adults and Old Women Fon (Figure 2). This is due to the fact that Adults and Old Women had a better grasp of technology than young people. This mastery of akandji production is the result of many years of experience (at least 15 years of service) and skill acquired. In fact, most of them came by inheritance through the transmission of knowledge from their mother, mother-in-law or grandmother (Figure 3), as was the case for ablo and gowé producers. Apart from these study areas, namely Abomey, Bohicon and Pahou, akandji is marketed in Adjra-Dovié, Godomey and even in Cotonou within the Dantokpa market thanks to mobile sales. These mobile resellers originate from the aforementioned production areas (Abomey, Bohicon and Pahou).

From an economic point of view, there was no fluctuation between the profits earned by women in the two localities (Table 3 ). These average profits in both localities ranged from $256 \mathrm{XOF}$ to $266 \mathrm{XOF}$. These results are similar 
to those of Bokossa et al. (2013a) which showed that the average profit received by gowé producers is $240 \mathrm{XOF}$. They are also close to that of Banon (2012), which showed that the average profit received by ablo producers varied between 220 XOF and 266 XOF. However, yields, unit price, cost of production and revenues varied. The higher yield in Abomey than in Pahou is explained by the differences observed between the unit operations that make up each technology. In fact, in Pahou, part of the flour from the grinding of the gritz was used for the production of porridge which was mixed with the rest of the flour. This was not the case in Abomey where all the flour from the malt milling was used for mixing. The akandji unit was sold cheaper in Abomey (25 XOF) than in Pahou (50 XOF) (Table 3). This is due to the addition of other ingredients (sourdough, sugar and salt) other than maize in the manufacture of akandji in Pahou, unlike Abomey where it was produced solely from maize. This justifies this fluctuation and by the same token, the high cost of production that was noticed in Pahou compared to that of Abomey (Table 3). The higher revenues in Pahou than in Abomey are due to the location of the sales activities. The sale at Pahou takes place on the Cotonou-Lomé interstate route. On the other hand, the sale in Abomey takes place in the local market which was animated every five days and occasionally for the ceremonies, in the houses (Table 3). Daily receipts do not vary significantly except for the minimum receipts for weekends and holidays which were higher in Abomey than in Pahou (Table 4). Indeed, in Pahou, the saleswomen could stay a whole day without selling all or part of their goods. On the other hand, in Abomey, they did not stay a day without making a recipe even if it is weak. However, revenues for weekends and holidays were higher than for business days. This increase is due to the travel of a large number of Beninese consumers and the organization of most ceremonies during the weekends as highlighted by Bokossa et al. (2013b).

Based on this study, it was found that all of the akandji producers surveyed used the white corn variety called Adjakouin as in the gowé production reported by Bokossa et al. (2013a). These surveys also allowed to identify two production technologies according to the localities. Abomey's production technology differs from that of Pahou on several points. At Abomey, the producers were malting the maize grains, adopting spontaneous fermentation and steaming. On the other hand, in Pahou, there was no malting, the fermentation was caused by the introduction of instant yeasts and the baking of the loaves was done in the oven (Table 6). This difference in production technology according to localities is due to the lack of optimization of parameters and the modeling of akandji production technologies.

In Abomey as in Pahou, the cost of crushing was the same. The temperature of fermentation did not change from one locality to another. Fermentation, however, took eight times longer in Abomey than in Pahou (1h30min in Pahou and 12h in Abomey). The duration of fermentation during the production of akandji in Abomey is close to that of ablo (Bokossa et al., 2013b) during its production in the localities of Abomey, Bohicon and Covè. Baking akandji justified the high temperature of this operation at Pahou $\left(178^{\circ} \mathrm{C} / 43 \mathrm{~min}\right)$ as opposed to Abomey where it was done at $100^{\circ} \mathrm{C} \mathrm{/} 60 \mathrm{~min}$ steam (Table 8). The production time was higher in Abomey (6 days) than in Pahou (about $5 \mathrm{~h}-6 \mathrm{~h}$ ) because of the grain malting operation during akandji production in Abomey. The long production time of akandji in both localities highlights the tedious nature of this production activity, as well as traditional cereal processing activities, as demonstrated by N'goran-Aw et al. (2017) as for the production of gnomy in Côte d'Ivoire. It must be recognized that, regardless of the region, producers packed the fermented dough before baking. Kokoéman banana leaves were used in Abomey while in Pahou, producers used the leaves of the great arum of Senegal «toungoman». This study has shown us that this traditional corn bread is a royal and historic food. Indeed, originally, akandji was prepared especially for the royal family during the demonstrations, but also for the warriors not 
only because of its ease of transport and its storability but also because of its energy input. It was also revealed to us by the producers of the two localities that in reality the akandji name given to this bread produced in Pahou is by abuse of language. Its real name is "ablo kpo $\mathrm{m} \varepsilon$ ton" which means in English "baked ablo". The identification of organoleptic characteristics according to localities shows that akandji produced at Pahou is whitish, hard, spongy, salty sweet acid (Figure 8). This spongy character is due to the action of yeast (instant yeasts) added for fermentation. The salty acid taste is justified by the acidic $\mathrm{pH}$ induced by fermentation and the addition of salt and sugar during the production of akandji. Akandji of Abomey was white, compact, less hard, acidic and sweet. The sweet taste observed at Abomey (while there is no addition of sugar in the process) is due to the hydrolysis of starch into soluble sugars during germination. Although akandji from the two technologies were smooth, it remained more in Abomey than in Pahou (Figure 8). Depending on the socio-cultural group, it is noted that akandji adult women lasted longer than Young Women Fon during conservation. This is due to the mastery and skill acquired during the many years of practice of Adult Women Fon who were generally producers and Young Women Fon who were resellers (Figure 10). The introduction of sugar and leaven into akandji at Pahou is also a favorable factor for the alteration of the product thus reducing its shelf life.

Table 2 : Socio-cultural profile of respondents.

\begin{tabular}{ll|l}
\hline \multicolumn{1}{c}{ Percentage (\%) } & Total $(\mathbf{n}=\mathbf{2 3})^{\mathbf{1}}$ \\
\hline Variables & Modalities & 0.0 \\
Categories & Producer & 21.7 \\
& Producer - Reseller & $\mathbf{7 8 . 3}$ \\
\hline \multirow{3}{*}{ Age } & Reseller & $\mathbf{5 6 . 5}$ \\
& Youth (0 to 35 years) & 39.2 \\
\hline Sex & Adults (35 to 60 years) & 4.3 \\
\hline \multirow{3}{*}{ Social status } & Older ( $>$ 60 years) & $\mathbf{1 0 0 . 0}$ \\
& Female & 4.3 \\
\hline Ethnicity & Merchant & 26.1 \\
\hline Nationality & Student & $\mathbf{6 9 . 6}$ \\
\hline \multirow{3}{*}{ Educational level } & Housewife & $\mathbf{1 0 0 . 0}$ \\
& Fon & $\mathbf{1 0 0 . 0}$ \\
\hline
\end{tabular}

Legend: $n=$ workforce

Table 3: Production yield, unit price, revenue, cost and profit per kilogram of akandji.

\begin{tabular}{lccccc}
\hline Parameters & \multicolumn{2}{c}{ Origin } & \multirow{2}{*}{ F - Value } & P \\
\cline { 2 - 4 } Yield (Loaves/Kg) & $30.00 \pm 0.00^{\mathrm{a}}$ & $21.52 \pm 0.41^{\mathrm{b}}$ & 38.63 & $<0.0001$ \\
Unit price (XOF) & $25.00 \pm 0.00^{\mathrm{b}}$ & $50.00 \pm 0.00^{\mathrm{a}}$ & Infin & $<0.0001$ \\
Revenues (XOF) & $750.00 \pm 0.00^{\mathrm{b}}$ & $1075.76 \pm 20.31^{\mathrm{a}}$ & 22.78 & $<0.0001$
\end{tabular}




$\begin{array}{llccc}\text { Production cost }(\text { XOF }) & 483.33 \pm 33.33^{\mathrm{b}} & 819.70 \pm 9.96^{\mathrm{a}} & 94.99 & <0.0001 \\ \text { Profit margin }(\text { XOF }) & 266.67 \pm 33.33^{\mathrm{a}} & 256.06 \pm 11.46^{\mathrm{a}} & 0.07 & 0.79\end{array}$

The affected values of the same letter on the same line are not significantly different at the $5 \%$ threshold (p < 0.05$)$; NB : Abomey : loaves weight $=614 \mathrm{~g}$

- Pahou : loaves weight $=593 \mathrm{~g}$

Table 4: Variation in daily receipts by locality.

\begin{tabular}{lcccc}
\hline \multicolumn{1}{c}{ Revenues (FCFA) } & Abomey & Pahou & F - Value & P \\
\hline RWDMin & $583.33 \pm 190.47^{\mathrm{a}}$ & $605.88 \pm 173.09^{\mathrm{a}}$ & 0.01 & 0.94 \\
RWDMax & $2583.33 \pm 153.66^{\mathrm{a}}$ & $3447.06 \pm 283.25^{\mathrm{a}}$ & 3.08 & 0.09 \\
RWHMin & $4000.00 \pm 408.25^{\mathrm{a}}$ & $3111.76 \pm 112.09^{\mathrm{b}}$ & 8.73 & 0.01 \\
RWHMax & $8083.33 \pm 746.29^{\mathrm{a}}$ & $8647.06 \pm 434.63^{\mathrm{a}}$ & 0.43 & 0.52
\end{tabular}

Legend: RWDMin: Recipes Working Days Minimum; RWDMax : Recipes Working Days Maximum RWHMin : Recipes Weekend Holidays Minimum ; RWHMax : Recipes Weekend Holidays Maximum.

The values carrying of the same letter on the same line are not significantly different at the $5 \%$ threshold.

Tableau 5 : Comparison of akandji production technologies.

\begin{tabular}{|c|c|c|}
\hline & Pahou & Abomey \\
\hline Ressemblances & \multicolumn{2}{|c|}{ Cleaning, washing, dripping, grinding, packing, firing } \\
\hline Dissemblances & $\begin{array}{l}\text { Crushing, sieving, preparation of corn } \\
\text { porridge, non spontaneous } \\
\text { fermentation, baking }\end{array}$ & $\begin{array}{c}\text { Malting, soaking, germination, sun } \\
\text { drying, spontaneous fermentation, } \\
\text { steam cooking }\end{array}$ \\
\hline
\end{tabular}

Table 6: Comparison of technological parameters.

\begin{tabular}{lcccc}
\hline \multirow{2}{*}{\multicolumn{1}{c}{ Distinctive parameters }} & \multicolumn{2}{c}{ Origins } & \multirow{2}{*}{ F-value } & p \\
\cline { 2 - 3 } & \multicolumn{1}{c}{ Abomey } & Pahou & & \\
\hline Grind cost / Kg (FCFA) & $50.00 \pm 0.00^{\mathrm{a}}$ & $58.33 \pm 8.33^{\mathrm{a}}$ & 0.60 & 0.49 \\
Fermentation temperature $\left({ }^{\circ} \mathbf{C}\right)$ & $27.50 \pm 2.50^{\mathrm{a}}$ & $31.33 \pm 0.88^{\mathrm{a}}$ & 3.08 & 0.18 \\
Fermentation time $(\mathbf{h})$ & $11.50 \pm 0.50^{\mathrm{a}}$ & $1.67 \pm 0.17^{\mathrm{b}}$ & 522.15 & 0.0002 \\
Firing temperature $\left({ }^{\circ} \mathbf{C}\right)$ & $100.00 \pm 0.00^{\mathrm{b}}$ & $178.33 \pm 4.41^{\mathrm{a}}$ & 189.34 & 0.0008 \\
Firing time (min) & $60.00 \pm 0.00^{\mathrm{a}}$ & $43.33 \pm 1.67^{\mathrm{b}}$ & 60.00 & 0.0045 \\
Production time (days) & $6.00 \pm 0.00^{\mathrm{a}}$ & $0.23 \pm 0.02^{\mathrm{b}}$ & 71829.60 & $<0.0001$ \\
\hline
\end{tabular}

The values carrying of the same letter on the same line are not significantly different at the $5 \%$ threshold. 
Table 7: Organoleptic characteristics of akandji.

\begin{tabular}{ll|c|c}
\hline \multicolumn{4}{c}{ Pourcentage (\%) } \\
\hline Variables & Modalities & $\begin{array}{c}\text { Atlantique } \\
(\mathbf{n = 1 7})^{\mathbf{1}}\end{array}$ & $\begin{array}{c}\text { Zou } \\
(\mathbf{n = 6})^{\mathbf{1}}\end{array}$ \\
\hline \multirow{2}{*}{ Hardness } & Hard & $\mathbf{8 8 . 2}$ & 00.0 \\
& Less hard & 11.8 & $\mathbf{1 0 0 . 0}$ \\
\hline \multirow{2}{*}{ Couleur } & White & 00.0 & $\mathbf{1 0 0 . 0}$ \\
& Whitish & $\mathbf{1 0 0 . 0}$ & 00.0 \\
\hline \multirow{2}{*}{ Flavour } & Sweet acid & $\mathbf{5 2 . 9}$ & $\mathbf{1 0 0 . 0}$ \\
& Sweet Salty Acid & 47.1 & 00.0 \\
\hline \multirow{2}{*}{ Aspect } & Smooth & $\mathbf{1 0 0 . 0}$ & $\mathbf{1 0 0 . 0}$ \\
& Rough & 00.0 & 00.0 \\
\hline \multirow{2}{*}{ Texture } & Compact & 00.0 & $\mathbf{1 0 0 . 0}$ \\
& Spongy & $\mathbf{1 0 0 . 0}$ & 00.0 \\
\hline
\end{tabular}

Legend: $\mathrm{n}$ = workforce

Table 8: Eigen values of the first two main components.

\begin{tabular}{cccc}
\hline Axe de PC & Eigen value & Proportion & Proportion cumulée \\
\hline PC1 & 0.50 & 0.97 & 0.97 \\
PC2 & 0.10 & 0.03 & $1.00^{*}$ \\
\hline
\end{tabular}

Table 9: Eigen value of the first three main components.

\begin{tabular}{lccc}
\hline Axe de PC & Eigen value & Proportion & Proportion cumulée \\
\hline PC1 & 0.351 & 0.73 & 0.73 \\
PC2 & 0.351 & 0.26 & $0.99^{*}$ \\
PC3 & 0.279 & 0.01 & 1.00 \\
\hline
\end{tabular}

\section{Conclusion}

This study shows akandji production is an exclusively female activity and economically profitable. It generates income and enables producers to meet their daily needs. The production technologies encountered in the field are dependent on empirical knowledge and constitute a heritage for producers. Two types of akandji have been identified in the field, one in Abomey and another in Pahou. These two varieties differ from the point of view of fermentation, but also from the point of view of cooking.

\section{COMPETING INTERESTS}

The authors declare that they have no competing interests.

\section{AUTHORS' CONTRIBUTIONS}

This work was carried out in collaboration among all authors. Authors TCKC and CIO designed the study, wrote the protocol, performed the statistical analysis and wrote the first draft of the manuscript. Authors dMR, GGJ, SSAP, BSJ and DA, managed the analyses of the study and performed the statistical analysis. Authors ATK, BTMR and BYPI managed the literature searches. All authors read and approved the final manuscript. 


\section{ACKNOWLEDGMENTS}

The authors thank all the collaborators from various laboratories of the national universities of Benin who contributed to the writing of this article.

\section{REFERENCES}

Adjanohoun A, Adjadi O, Lokossou C, Azelokonon OG, Bankole CD, Djinadou AK, Ahoyo Adjovi RN. 2015. Recueil de Mets et de Boissons à Base de Mä̈s Consommés au Bénin. INRAB : Cotonou ; p. 156.

Aholou-Yeyi AM. 2007. Evaluation du système technique artisanal de production d'Ablo, un pain cuit à la vapeur. Thèse d'Ingénieur Agronome, Faculté des Sciences Agronomiques, Université d'Abomey-Calavi, Bénin, p. 61.

Assogbadjo AE, Glèlè Kakaï R, Chadare FJ., Thomson L, Kyndt T, Sinsin B, Van Damme P. 2008. Folk classification. Perception and preferences of baobab products in West Africa: consequences for species conservation and improvement. Economic Botany, 62 (1): 74-84. https://doi.org/10.1007/s12231007-9003-6

Balogoun I, Saidou A, Ahoton EL, Amadji GL, Ahohuendo CB, Adébo JB, Babatoundé $\mathrm{S}$, Chougourou D, Adoukonou SH, Ahanchédé A. 2014. Caractérisation des systèmes de production à base d'anacardier dans les principales zones de culture au Bénin. Agronomie Africaine, 26 (1) : 9-22.

Banon SBJ. 2012. Evolution de la flore microbienne au cours de la fermentation d'un produit alimentaire fermenté du Bénin : cas de ablo. Mémoire de Master, FAST/UAC, Bénin, p. 57.

Bello OD, Ahoton LE, Saidou A, Akponikpè IPB, Ezin VA, Balogoun I, Aho N. 2017. Climate change and cashew (Anacardium Occidentale L.) productivity in Benin: perceptions, endogenous measures of adaptation. Int. J. Biol. Chem. Sci., 11(3): 924-946.

DOI: https://dx.doi.org/10.4314/ijbcs.v11i3.1
Bokossa Yaou I, Tchekessi CKC, Banon J, Agbangla C, Adeoti K, Dossou-Yovo P. 2013a. Etude socio-économique de production d'une pâte traditionnelle fermentée "gowé" fabriquée à base de maïs au Bénin. J. Rech. Sci. Univ. Lomé (Togo), 15(3) : 53-63.

Bokossa Yaou I, Banon JBS, Tchekessi CKC, Dossou-Yovo P, Adeoti K, Assogba E. 2013b. Evaluation socio-économique de la production de ablo, une pâte de maïs fermentée du Bénin. Bulletin de la Recherche Agronomique $d u$ Bénin (BRAB), 35-40.

Charcosset A, Gallais A. 2009. Emergence et développement du concept de variétés hybrides chez le maïs. 'Le Sélectionneur Français". UMR Génétique Végétale. INRA-Université de Paris-SudCNRSAgroParisTechFerm du moulin 91190GIF/YVETTE, $60:$ 21-30,

Dagnelie P. 1986. Théorie et Méthodes Statistiques. Applications Agronomiques (Vol 2). Les Presses Agronomiques de Gembloux, A.S.B.L. (Belgique) ; p. 463.

Dossou J, Ballogou VY, Dabadé DS, Dakpo M. 2015. Analyse économique de la production artisanale du chakpalo au Bénin : aspects sociaux et facteurs déterminants de la rentabilité financière de l'activité. Journal of Applied Biosciences, $\quad 87$ : 8065-8075. DOI: 10.4314 /jab.v87i1.7

FAO. 2009. Promesses et défis du secteur alimentaire informel dans les pays en développement. Division de la communication, FAO, Rome, Italie, p. 40.

Gnanglè PC, Glèlè Kakaï R L, Assogbadjo AE, Vodounon S, Yabi JA, Sokpon N. 2011. Tendances climatiques passées, modélisation, perceptions et adaptations locales au Bénin. Climatologie, 8: 26-40. https://doi.org/10.4267/climatologie.259

Moussé YF. 2018. Production, caractérisations microbiologique et physico-chimique de la denrée alimentaire «foura » produite au Bénin. Mémoire pour l'obtention du diplôme de Master en Microbiologie et 
Technologie Alimentaire. Université d'Abomey-Calavi, p. 76.

Nago MC, Hounhouigan D.J. 1990. La technologie traditionnelle de transformation du maïs en pâte fermentée au Bénin. Rapport de recherche ${ }^{\circ} 1$, FSAIRAT-CEE, 30p. Rapport d'étude, Abomey-Calavi, Benin, FSA/UNB, p. 222.

N'goran-A EBZ, Soro D, Aw S, Akaki KD, Assidjo NE. 2017. Evaluation des caractéristiques physico-chimiques et microbiologiques d'un beignet traditionnel à base de mil fermenté (gnomy) commercialisé dans la ville de Yamoussoukro (Côte d'Ivoire). European Scientific Journal, 13(9): 227241. https://doi.org/10.19044/esj.2017.v $13 \mathrm{n} 9 \mathrm{p} 227$

Norusis MJ. 2002. SPSS 11.0 guide to data analysis. Prentice and Hall. Rimi, R. H., Rahman, S. H., Karmakar, S. \& Ghulam, H. S.K. 2011. Trend Analysis of Climate Change and Investigation on Its Probable Impacts on Rice Production at Satkhira, Bangladesh, Pakistan. Journal of Meteorology, 6(1): 37-50.

Nuss TE, Tanumihardjo SA. 2011. Quality Protein e for Maize Africa: Closing the protein inadequacy gap in vulnerable populations. Adv. Nutr., 2: 217-224. DOI: $10.3945 /$ an.110.000182

Onzo FC, Azokpota P, Akissoé N, Agbani OP. 2013. Biodiversité des emballages- feuilles végétales utilisées dans l'artisanat agroalimentaire au Sud du Bénin. J. Appl. Biosci., 72 : 5810 - 5821. DOI: $10.4314 /$ jab.v72i1.99666.

Tchekessi CKC, Bokossa Yaou I, Hounkpatin GJ F, Banon J, Adigun N, Sachi P, Agbangla C. 2014. Socio-economic and technological study of manufacture of the pellets of cereals for the production of a fermented drink of probiotic type consumed in Benin. International Journal of Innovation and Applied Studies, 9(3):1323-1335.

Tchekessi CKC, Bokossa Yaou I, Banon J, Agbangla C, Adéoti K, Dossou-Yovo P, Assogba E. 2013. Caractérisations physico-chimiques et microbiologiques d'une pâte traditionnelle "gowé" fabriquée à base de maïs au Bénin. $J$. Rech. Sci. Univ. Lomé, 15(2) : 91-101.

Tchekessi CKC. 2012. Caractérisations physico-chimiques et microbiologiques d'une pâte traditionnelle "gowé" fabriquée à base de maïs au Bénin. Mémoire de Master, FAST / UAC, Bénin, p. 51.

Wilhelm M. 2014. Rapport de méthodes Echantillonnage boule de neige, la méthode de sondage déterminé par les répondants ; Université de Neuchâtel ; ed. Office Fédéral de la Statistique (OFS), p. 60. 